\title{
Phytochemical Investigation and Characterization on the Root Bark Extract of Prunus Africana
}

\author{
Teshale Ayano Begeno \\ Department of Chemistry, College of Natural and Computational Science, Wolkite University, Ethiopia. \\ P.O.Box: 07 Wolkite University, Wolkite, Ethiopia
}

\begin{abstract}
Prunus africana is one of the most popular to treat benign prostate hyperplasia (BHP), and to treat diarrhoea, dysmenorrhoea, infertility, irregular menstruation, kidney disease, disorders, fevers, obesity, pneumonia, hypertension, antigonorrheic, antimalarial, chest pain; other various diseases. The air dried and powdered plant material $(200 \mathrm{~g})$ was first soaked with $500 \mathrm{~mL}$-hexane for 72 hours and yielded $1.3 \mathrm{~g}$ of $\mathrm{n}$-hexane extract. Marc was soaked with $400 \mathrm{~mL}$ of ethyl acetate for 72 hours and afforded $2 \mathrm{~g}$ of ethyl acetate extract. Finally, Marc was soaked with $400 \mathrm{~mL}$ of methanol and yielded $12.6 \mathrm{~g}$ of methanol extract. The ethyl acetate extract of the root bark of $P$. africana afforded a compound coded as AYU. Its Structural determination was accomplished by means of spectroscopic techniques, namely IR, ${ }^{1} \mathrm{H}$ NMR, ${ }^{13} \mathrm{C}$ NMR and DEPT-135. The compound, AYU was isolated and characterized from the root bark of $P$. african. It was shown that spot on TLC only up on spraying $1 \%$ vanillin sulphuric acid and after heating for a few minutes. Generally, chromatographic techniques like PTLC and HPLC are required to isolate more compounds from leaves of $P$. africana. Also MS and 2D NMR spectroscopic techniques are needed to fully characterize the isolated compound.
\end{abstract}

Keywords: P.africana; benign prostate hyperplasia; characterization; chromatographic techniques; spectroscopic techniques.

DOI: $10.7176 / \mathrm{CMR} / 12-6-02$

Publication date:July $31^{\text {st }} 2020$

\section{Introduction}

Plants have long history of being used for a wide variety of purposes including food, clothing, shelter, tools, weapons, and therapeutic agents. ${ }^{1}$ phytochemical study of plants is of the great importance in developing drugs. Drugs are strictly defined as chemical substances that are used to prevent or cure diseases in humans, animals and plants. Drugs from natural products are secondary metabolites and their derivatives. Natural products have been a major source of drugs for centuries, with more than $25 \%$ of the pharmaceuticals in use today derived from natural products. Natural product chemistry is a part of organic chemistry that covers the chemistry of naturally occurring organic compounds: their biosynthesis, function in their environment, metabolism and more conventional branches of chemistry such as structural elucidation and synthesis. Primary metabolism is the system of biochemical reactions whose products are vital for their life cycles. Secondary metabolism refers to the functions of an organism yielding products that are not necessary for the essential biochemical events. Secondary metabolites are thus compounds which are often species dependent. The most challenge of human civilization is getting the proper drug treatment. According to the World Health Organization (WHO) estimation that around $80 \%$ of the world population in developing countries relies on traditional medicines for primary health care needs, of which a major proportion corresponds to plant extracts. ${ }^{2}$ The World Health Organization has also recognized the importance of traditional medicine and has created strategies, guidelines and standards for botanical medicines. ${ }^{3}$ From $70-95 \%$ of citizens in a majority of developing countries like in Asia, Africa, Latin America and the Middle East use traditional medicine for the management of primary health care. A survey made by the World Health Organization (WHO) showed that $70-90 \%$ populations of some industrialized nations like Canada, France, Germany and Italy, for instance, are using traditional medicines under the title "complementary" or "alternative" medicines. The survey also showed that in some African countries like Ghana, Mali, Nigeria and Zambia, around $60 \%$ of children due to malaria are treated at home with herbal medicine. ${ }^{1}$ Worldwide, infectious diseases are the leading causes of death accounting for approximately one half of all deaths in tropical countries and a significant problem in developed nations. It is estimated that infectious diseases are the underlying causes for $8 \%$ deaths occurring in US. Despite the use of herbal medicines over many centuries of the world, only a relatively small number of plant species has been studied for possible medical applications. ${ }^{4}$

\subsection{Prunus africana (P. africana)}

P. africana is a geographically widespread tree to forest habitats of the African continent. It is an evergreen hardwood tree; over $30 \mathrm{~m}-60 \mathrm{~m}$ in height and up to 1.5 meter diameter. The leaves are simple and alternately arranged. The flowers are small, androgynous, and insect-pollinated. It is known commonly as African cherry or Pygeum africanum. The Rosaceae family includes many well known and beloved species of economic importance particularly edible temperate zone fruits, ornamentals and some important medicinal plants. ${ }^{5,6}$ The Rosaceae is the 
$19^{\text {th }}$ largest family of plant and it includes more than 100 genera and 2830-3100 species among which P.africana has well claimed medicinal value. It is widely distributed in Angola, Mozambique, Zambia, Zimbabwe, Burundi, Congo, Kenya, Rwanda, Sudan, Tanzania, Uganda, Cameroon, Nigeria, Sao Tome, and Ethiopia (northwest highlands, southeast Highlands Harerge, Illubabor, Kefa, Arsi and Wolega). ${ }^{5}$

\subsection{P. africana Species and Their medicinal uses}

The known Prunus species are plums (P. domestica L.), cherries (P. avium L.), peaches (P. persica L.), almonds (P. dulcis), and apricots (P. armeniaca L.). All of them are commercially interesting species. ${ }^{7}$ It is most popular to treat benign prostate hyperplasia (BHP) which is a non-cancerous enlargement of the prostate all over the world. Traditional healers across Africa use P. africana as a medicine to treat diarrhoea, dysmenorrhoea, epilepsy, impotency, infertility, irregular menstruation, kidney disease, mental illness, eye disorders, fevers, obesity, pneumonia, arthritis, haemorrhage, hemorrhoids, hypermenorrhea, hypertension, prostate gland enlargement , antigonorrheic, antihelmentic, anti-inflammatory, antimalarial, chest pain, antiparasiticide and anti-rheumatic. ${ }^{5,8}$ The pharmacological efficacy is believed to be due to various compounds of known and unknown. Among the known compounds, three groups are great important: (A) phytosterols especially $\beta$-sitosterol, have antiinflammatory properties that inhibit the swelling of the prostate gland, (B) pentacyclic triterpenoids that provide anti-edematous activity, and (C) ferulic acid esters, which have a powerful hypocholestero-lernic activity in the prostate, as well as anti-tumor activity. ${ }^{9}$ Leaves are used as an inhalant for fever or are drunk as an infusion to improve appetite. ${ }^{10}$ It is also used as a remedy for stomach pain, and insanity. ${ }^{11}$

\subsection{Uses of P. africana with Exploitation}

The discovery of the medicinal properties of Prunus bark initiated a decades' long harvest for international market needs, in which Cameroon supplied over half, followed by Madagascar, the Democratic Republic of the Congo (DRC), Kenya, Uganda, and Equatorial Guinea. ${ }^{7}$ For the last 35 years, the African cherry (P. africana) has been used in the treatment of benign prostatic hyperplasia and other disorders. The bark, from which the treatment is derived, is entirely wild-collected. The major exporters of bark include Cameroon, Madagascar, Equatorial Guinea, and Kenya. To the group of Fournier France, Indian, and Italy which exported $86 \%$ of the world bark extracts. Worldwide exports of dried bark in 2000 have been estimated at 1350-1525 metric tons per year, down from its peak of 3225 tons in 1997 . Bark extracts $\left(6370-7225 \mathrm{~kg}\right.$ per year) are worth an estimated $\$ 4.36$ million per year. ${ }^{11}$ While, in Ethiopia, the African cherry is basically used for fuel wood, charcoal, ornamental, windbreaks and green manure. ${ }^{12}$ Bark infusions were used in the treatment of chest pains and as a purgative for cattle. ${ }^{13}$ In Africa, 500 tonnes of bark were harvested for use in traditional medicine annually. ${ }^{14}$ The use of the species in pharmaceutical industry commercially began in 1970s. In 1980, only 200 tonnes of $P$. africana bark were harvested. ${ }^{15}$ The demand for the bark in pharmaceutical industry increased from then and by 1997 the demand had risen to 3500 tonnes. $^{16}$ This involved processing and marketing of bark and bark extracts for the treatment of benign prostate hyperplasia. ${ }^{17}$ Benign prostatic hyperplasia (BPH) is a condition common in most men and manifests itself as increased frequency in urination, pain in passing urine, inability to empty the bladder and post urinary dribbling. ${ }^{18}$ Phytosterols eliminate vassal congestion and excess blood hence reduces the size of prostate adenomas. The pentacyclic triterpenoids block enzymatic activity consequently inhibits inflammation in the prostate. ${ }^{19,}{ }^{20}$ Thus, the study was aimed at phytochemical investigation and characterization, on the root bark of P.africana.

\section{Materials and Methods \\ 2.1 Plant Material}

The root bark of P. africana was collected from Shero kebele borderline of Abose and Weshiso land, Misha Woreda, Hadiya Administrative Zone, Southern Nations Nationalities and People Regional State.

\subsection{Instruments, Apparatus and Chemicals}

${ }^{1} \mathrm{H}$ and ${ }^{13} \mathrm{C}$ NMR spectra were recorded on a Bruker Advance $400 \mathrm{MHz}$ spectrometer in $\mathrm{CDCl}_{3}$ with $\mathrm{TMS}$ as internal started. The ultra-violet and visible (UV-Vis) spectra were taken on GENESY'S 2PC UV-Vis scanning spectrometer (200-800 nm). IR spectra were obtained on Perkin-Elmer BX infrared spectrometer (400-4000 $\mathrm{cm}^{-}$ $\left.{ }^{1}\right)$ using $\mathrm{KBr}$. Melting point was recorded using digital melting point apparatus. Analytical thin layer chromatograms were run on $0.2 \mathrm{~mm}$ thick layer of silica gel coated on aluminum foil. Column chromatography was performed using silica gel (70-230 mesh). List of solvents were used in this research like: n-hexane, ethyl acetate, methanol and others. Some of the apparatus were used: funnels, round bottom flasks, vials, glass wares, refrigerator, Whatman No.1 filter papers, grinder, drying oven, measuring cylinders, TLC Chamber, capillary tubes, cuvette quartz etc...

\subsection{Extraction and Isolation}

The air dried and powdered plant material $(200 \mathrm{~g})$ was first soaked with $500 \mathrm{ml} \mathrm{n}$-hexane for 72 hours and the 
extract was collected by filtering and concentrated under reduced pressure using the Rotavapor and yielded $1.3 \mathrm{~g}$. The solvent free Marc was then soaked with $400 \mathrm{ml}$ of ethyl acetate for 72 hours and the extract was collected. This filtrate was evaporated under reduced pressure using the Rotavapor and afforded $2 \mathrm{~g}$. Finally, the solvent free Marc was soaked with $400 \mathrm{ml}$ of methanol, and then it was filtrated by using Whatman no.1 filter paper and concentrated under reduced pressure using the Rotavapor and it was yielded sample of $12.6 \mathrm{~g}$, and its extract was afforded many spots on TLC. Solvent was removed using rotary evaporator. Compound on TLC was detected after spraying 1\% vanillin sulphuric acid and after heating for a few minutes. There was no visible spot for $n$-hexane extract, but ethyl acetate extracts were showed three colored spots by using solvent system of n-hexane: ethyl acetate (6:4), and its yield of $2 \mathrm{~g}$ crude extract was dissolved in itself with equivalent amount of silica gel, dried using Rotavapor and applied to a silica gel $(200 \mathrm{~g})$ column chromatography which was packed with n-hexane $(100 \%)$.

Table1: The column chromatography elution of $P$. africana root bark extract with their respective volumes and masses

\begin{tabular}{|c|c|c|c|c|c|c|c|c|}
\hline $\begin{array}{l}\text { No. of } \\
\text { fractions }\end{array}$ & $\begin{array}{l}\text { Volume } \\
\text { (mL) }\end{array}$ & $\begin{array}{l}\text { Mass } \\
\text { (mg) }\end{array}$ & $\begin{array}{l}\text { No. of } \\
\text { fractions }\end{array}$ & $\begin{array}{l}\text { Volume } \\
\text { (mL) }\end{array}$ & $\begin{array}{l}\text { Mass } \\
\text { (mg) }\end{array}$ & $\begin{array}{l}\text { No. of } \\
\text { fractions }\end{array}$ & $\begin{array}{l}\text { Volume } \\
\text { (mL) }\end{array}$ & $\begin{array}{l}\text { Mass } \\
\text { (mg) }\end{array}$ \\
\hline 1 & 20 & 1.700 & 50 & 20 & 3.327 & 81 & 20 & 4.821 \\
\hline 2 & 20 & 2.400 & 51 & 20 & 7.654 & 82 & 20 & 2.813 \\
\hline 3 & 20 & 5.100 & 52 & 20 & 9.371 & $83-94$ & 240 & - \\
\hline 4 & 20 & 2.700 & 53 & 20 & 13.500 & 95 & 20 & 0.520 \\
\hline 5 & 20 & 4.100 & 54 & 20 & 5.500 & 96 & 20 & 0.038 \\
\hline 6 & 20 & 5.100 & 55 & 20 & 7.974 & 97 & 20 & 0.068 \\
\hline 7 & 20 & 3.700 & 56 & 20 & 3.500 & 98 & 10 & 1.047 \\
\hline 8 & 20 & 4.900 & 57 & 20 & 4.852 & 99 & 10 & 0.841 \\
\hline 9-27 & 380 & - & 58 & 20 & 7.469 & 100 & 10 & 2.039 \\
\hline 28 & 20 & 40.490 & 59 & 20 & 5.374 & $101-164$ & 640 & - \\
\hline 29 & 20 & 63.470 & 60 & 20 & 4.346 & 165 & 10 & 0.024 \\
\hline 30 & 20 & 76.214 & 61 & 20 & 3.421 & 166 & 10 & 0.019 \\
\hline 31 & 20 & 87.090 & 62 & 20 & 0.6784 & 167 & 10 & 1.072 \\
\hline 32 & 20 & 120.670 & 63 & 20 & 7.204 & 168 & 10 & 2.008 \\
\hline 33 & 20 & 94.050 & 64 & 20 & 9.063 & $168 \mathrm{~A}$ & 50 & 6.005 \\
\hline 34 & 20 & 56.478 & 65 & 20 & 1.845 & 169 & 50 & - \\
\hline 35 & 20 & 100.290 & 66 & 20 & 4.562 & $170-195$ & 260 & - \\
\hline 36 & 20 & 83.940 & 67 & 20 & 1.784 & & & \\
\hline 37 & 20 & 68.326 & 68 & 20 & 2.453 & & & \\
\hline 38 & 20 & 78.192 & 69 & 20 & 1.963 & & & \\
\hline 39 & 20 & 39.156 & 70 & 20 & 7.270 & & & \\
\hline 40 & 20 & 41.345 & 71 & 20 & 2.846 & & & \\
\hline 41 & 20 & 35.094 & 72 & 20 & 0.248 & & & \\
\hline 42 & 20 & 44.220 & 73 & 20 & 0.251 & & & \\
\hline 43 & 20 & 54.021 & 74 & 20 & 3.618 & & & \\
\hline 44 & 20 & 12.355 & 75 & 20 & 24.380 & & & \\
\hline 45 & 20 & 12.114 & 76 & 20 & 9.0531 & & & \\
\hline 46 & 20 & 13.980 & 77 & 20 & 4.731 & & & \\
\hline 47 & 20 & 27.139 & 78 & 20 & 6.039 & & & \\
\hline 48 & 20 & 57.275 & 79 & 20 & 0.371 & & & \\
\hline 49 & 20 & 61.723 & 80 & 20 & 3.521 & & & \\
\hline
\end{tabular}

Key: sign (-) indicates the absence of mass.

The numbers of fractions were collected. Out of these fractions which were collected using the solvent systems increased polarity, some of them were showed the characteristic colored spots on TLC up on spraying $1 \%$ vanillin sulphuric acid and after heating for a few minutes. The remaining fractions did not show the characteristic colored spots on TLC up on spraying 1\% vanillin sulphuric acid and after heating for a few minutes. Among fractions, fraction 58 showed single spot on TLC using the solvent system n-hexane: ethyl acetate (6:4) upon spraying $1 \%$ vanillin sulphuric acid and after heating for a few minutes. Finally, the dried sample of this fraction was afforded $17 \mathrm{mg}$ of the compound, AYU.

\section{Results and Discussion}

3.1 Phytochemical Screening of root bark extract of $P$. africana

The extracts phytochemical analysis for identification of chemical constituents was done using standard procedures from literature. 
1. Tannins: About $0.1 \mathrm{~g}$ of the extract was put in a test tube and $20 \mathrm{~mL}$ of distilled water was added and heated to boiling. The mixture was then filtered and $0.1 \%$ of $\mathrm{FeCl}_{3}$ was added to the filtrate and observations made. A brownish green color or a blue-black coloration indicated the presence of tannins.

2. Saponins: About $0.1 \mathrm{~g}$ of the extract was mixed with $5 \mathrm{~mL}$ of water and vigorously shaken. The formation of stable form indicated the presence of saponins.

3. Flavonoids: About $0.1 \mathrm{~g}$ of the extract was added in to a test tube. To the test tube $5 \mathrm{~mL}$ of dilute ammonia and $2 \mathrm{~mL}$ of concentrated sulphuric acid was added and heated for about 2 minutes. The appearance of a yellow color indicated the presence of flavonoids.

4. Terpenoids: About $0.1 \mathrm{~g}$ of the extract was taken in a clean test tube; $2 \mathrm{~mL}$ of chloroform was added and vigorously shaken, then evaporated to dryness. To this, $2 \mathrm{~mL}$ of concentrated sulphuric acid was added and heated for about 2 minutes. A grayish color indicated the presence of terpenoids.

5. Glycosides: About $0.1 \mathrm{~g}$ of the extract was mixed with $2 \mathrm{~mL}$ of chloroform and $2 \mathrm{~mL}$ of concentrated sulphuric acid was carefully added and shaken gently, then the observations were made. A red brown color indicate the presence of steroidal ring (glycone portion of glycoside)

6. Alkaloids: About $0.1 \mathrm{~g}$ of the extract was mixed with $1 \%$ of $\mathrm{HCl}$ in a test tube. The test tube was then heated gently and filtered. To the filtrate a few drops of Wagner's reagents were added by the side of the test tube. A resulting precipitate confirmed the presence of alkaloids.

7. Steroids: About $0.1 \mathrm{~g}$ of the extract was put in a test tube and $10 \mathrm{~mL}$ of chloroform added and filtered. Then $2 \mathrm{~mL}$ of the filtrate was mixed with $2 \mathrm{~mL}$ of a mixture of acetic acid and concentrated sulphuric acid. Bluish green ring indicated the presence of steroids.

8. Phenols: About $0.1 \mathrm{~g}$ of the extract was put in a test tube and treated with a few drops of $2 \% \quad$ of $\mathrm{FeCl}_{3}$; blue green or black coloration indicated the presence of phenols. ${ }^{21}$

Table 2: Results of phytochemical screening of root bark extract of $P$. africana

\begin{tabular}{llc}
\hline Phytochemical Constituents & \multicolumn{2}{c}{ Extracts } \\
\cline { 2 - 3 } Tannins & Ethyl acetate & Hexane \\
Saponins & + & + \\
Flavonoids & + & + \\
Terpenoids & + & - \\
Glycosides & + & + \\
Alkaloids & + & - \\
Steroids & + & + \\
Phenols & + & + \\
\hline
\end{tabular}

Key: + indicates presence of chemical Constituents and indicates absence of chemical Constituents

The air dried and powdered leaves of the P. africana $(200 \mathrm{~g})$ were extracted with solvents of n-hexane, ethyl acetate and methanol. These extracts when developed on TLC both the n-hexane and ethyl acetate extracts have shown three colored spots, but methanol extract was afforded many spots on TLC. The orange organic extract of ethyl acetate $(2 \mathrm{~g})$ was subjected to column chromatography on silica gel.

\subsection{Characterization of Compound, AYU}

The compound, AYU was obtained as a white solid that showed a characteristic color change to violet on TLC plate upon spraying $1 \%$ vanillin sulphuric acid and after heating for a few minutes. It has retention factor, RF value 0.8 using hexane: ethyl acetate (6:4) as solvent system. In the IR spectrum of the compound, AYU the absorption band at $3400 \mathrm{~cm}^{-1}$ showed the $\mathrm{O}-\mathrm{H}$ stretching that indicated the presence of a hydroxyl group. The strong absorption band at $2922 \mathrm{~cm}^{-1}$ showed the presence of the $\mathrm{C}-\mathrm{H}$ stretching of the olefinic group. The weak absorption band at $2850 \mathrm{~cm}^{-1}$ showed the presence of the $\mathrm{C}-\mathrm{H}$ stretching for $\mathrm{sp}^{3}$ groups. Two strong absorption band at $1690 \mathrm{~cm}^{-1}$ and $1609 \mathrm{~cm}^{-1}$ showed the presence of the olefinic $\mathrm{C}=\mathrm{C}$ stretching. The absorption band at $1170 \mathrm{~cm}^{-1}$ showed the presence of the $\mathrm{C}-\mathrm{O}$ bond stretching.

Table 3: IR spectral peak values and functional groups obtained from the root bark extract of P. africana (AYU)

\begin{tabular}{|l|l|l|}
\hline Extract prepared in & peak values in $\mathrm{cm}^{-1}$ & functional groups \\
\hline \multirow{5}{*}{ Ethyl acetate } & 3400 & $-\mathrm{OH}$ (hydroxyl group) \\
\cline { 2 - 3 } & 2922 & $\mathrm{Sp}^{2} \mathrm{C}-\mathrm{H}$ stretching \\
\cline { 2 - 3 } & 2850 & $\mathrm{SP}^{3} \mathrm{C}-\mathrm{H}$ stretching \\
\cline { 2 - 3 } & 1690 and 1609 & Olefinic group of $\mathrm{C}=\mathrm{C}$ stretching \\
\cline { 2 - 3 } & 1468 & Methylene group bending \\
\cline { 2 - 3 } & 1358 & Methyl group bending \\
\cline { 2 - 3 } & 1170 & $\mathrm{CO}$ bond stretching \\
\hline
\end{tabular}

The ${ }^{1} \mathrm{H}$ NMR spectrum showed ttiplet peaks at $\delta$ 5.29, integrating for one proton, corresponded to the methine 
proton groups and assigned to C-1. Coupled proton peaks, which is triplet peaks at $\delta 2.10 ; 1.99$, integrating for two protons, which were corresponded to the methylene proton groups and assigned to $\mathrm{C}-2$. The pentet peaks at $\delta$ 3.41 , integrating for one proton, corresponded to the methine proton group that assigned at C-3. Coupled proton peaks, which is triplet peaks at $\delta 1.89 ; 1.60$, which integrating for two protons corresponded to the methylene proton groups and attached to $\mathrm{C}-4$. Triplet peaks at $\delta 1.90$, integrating for one proton corresponded to the methine proton, which were assigned to C-5. The quartet peaks at $\delta 3.3$, integrating for one proton, corresponded to the methine proton and assigned to C-9. Coupled proton peaks, which is doublet peaks at $\delta 2.30 ; 2.10$, integrating for two protons corresponded to the methylene proton which was attached to C-11. The pentet peaks at $\delta 2.10$ which integrating for one proton corresponded to the methine proton and attached to $\mathrm{C}-12$. Coupled proton peaks, which is doublet peaks at $\delta 2.30 ; 2.10$, which integrating for two protons corresponded to the methylene proton and attached to $\mathrm{C}-13$. Singlet peak at $\delta 1.20$ which integrating for six protons corresponded to the methyl protons and attached to $\mathrm{C}-14$ and $\mathrm{C}-15$. Doublet peaks at $\delta 1.10$, which integrating for three protons corresponded to the methyl protons and attached to $\mathrm{C}-16$. Doublet peaks at $\delta 1.23$, which integrating for three protons corresponded to the methyl protons and it attached to C-17.

The ${ }^{13} \mathrm{C}$ NMR and DEPT-135 spectrum of compound, AYU showed well resolved resonance of $17 \mathrm{C}$ atoms of which 4, 4, 5, and 4 of them were methyl, methylene, methine, and quaternary carbon groups, respectively. Table 4: ${ }^{1} \mathrm{H}$ NMR spectral data of compound (AYU)

\begin{tabular}{|c|c|c|c|c|c|}
\hline S. No. & Peaks $(\delta)$ & Peak multiplicities & Proton No. & Assigned carbon & Remark \\
\hline 1 & 5.29 & Triplet & One & $\mathrm{C}-1$ & Methine \\
\hline 2 & $2.10 ; 1.99$ & Triplet & Two & $\mathrm{C}-2$ & methylene \\
\hline 3 & 3.41 & Pentet & One & $\mathrm{C}-3$ & Methine \\
\hline 4 & $1.89 ; 1.60$ & Triplet & Two & $\mathrm{C}-4$ & Methylene \\
\hline 5 & 1.90 & Triplet & One & $\mathrm{C}-5$ & methine \\
\hline 6 & 3.30 & Quartet & One & C-9 & Methine \\
\hline 7 & $2.30 ; 2.10$ & Doublet & Two & C-11 & Methylene \\
\hline 8 & 2.10 & Pentet & One & $\mathrm{C}-12$ & Methine \\
\hline 9 & $2.30 ; 2.10$ & Doublet & two & C-13 & methylene \\
\hline 10 & 1.20 & Singlet & Six & C-14 and C-15 & Methyl \\
\hline 11 & 1.10 & Doublet & Three & $\mathrm{C}-16$ & Methyl \\
\hline 12 & 1.23 & Doublet & Three & $\mathrm{C}-17$ & Methyl \\
\hline
\end{tabular}

The ${ }^{13} \mathrm{CNMR}$ and DEPT-135 spectrum of compound (AYU) showed well resolved resonance of 17 carbon atoms and from them were: four methyl groups, four methylene groups, five methine groups and four quaternary carbons.

Table 5: ${ }^{13} \mathrm{C}$ NMR and DEPT-135 $\left(400 \mathrm{MHz}, \mathrm{CDCl}_{3}\right)$ spectral data of Compound (AYU)

\begin{tabular}{llll}
\hline Carbon No. & ${ }^{\mathbf{1 3}} \mathbf{C}$ NMR (in ppm) & DEPT (in ppm) & Remark \\
\hline $\mathbf{1}$ & 122.66 & 122.65 & $\mathrm{CH}$ \\
$\mathbf{2}$ & 35.61 & 35.62 & $\mathrm{CH}_{2}$ \\
$\mathbf{3}$ & 68.00 & 68.00 & $\mathrm{CH}$ \\
$\mathbf{4}$ & 33.00 & 33.10 & $\mathrm{CH}_{2}$ \\
$\mathbf{5}$ & 41.55 & 41.52 & $\mathrm{CH}$ \\
$\mathbf{6}$ & 32.96 & - & $\mathrm{C}$ (Quaternary carbon) \\
$\mathbf{7}$ & 140.87 & - & $\mathrm{C}$ (Quaternary carbon) \\
$\mathbf{8}$ & 129.9 & - & $\mathrm{C}$ (Quaternary carbon) \\
$\mathbf{9}$ & 52.20 & 52.21 & $\mathrm{CH}$ \\
$\mathbf{1 0}$ & 139.05 & - & $\mathrm{C}($ Quaternary carbon) \\
$\mathbf{1 1}$ & 40.08 & 40.08 & $\mathrm{CH}$ \\
$\mathbf{1 2}$ & 23.21 & 23.22 & $\mathrm{CH}$ \\
$\mathbf{1 3}$ & 39.00 & 39.10 & $\mathrm{CH}_{2}$ \\
$\mathbf{1 4}$ & 25.90 & 25.86 & $\mathrm{CH}_{3}$ \\
$\mathbf{1 5}$ & 25.90 & 25.86 & $\mathrm{CH}_{3}$ \\
$\mathbf{1 6}$ & 24.72 & 24.71 & $\mathrm{CH}_{3}$ \\
$\mathbf{1 7}$ & 20.41 & 20.40 & $\mathrm{CH}_{3}$ \\
\hline
\end{tabular}

Finally, from the all above data, namely IR spectral data, ${ }^{13} \mathrm{C}$ NMR, DEPT-135 and ${ }^{1} \mathrm{H}$ NMR spectral data the proposed structure of compound (AYU) would be shown below: 


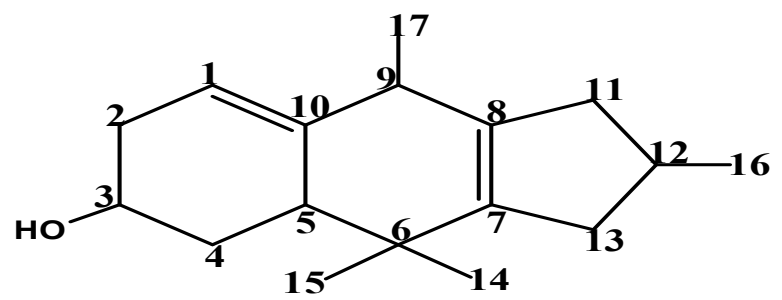

Fig. 1. The proposed structure of the compound, AYU

Key: $\mathrm{AYU}=$ code, which was given for proposed structure, there is no other meaning

\section{Conclusions and Recommendations}

P. africana is a commercial by its stem bark which is most popular to treat benign prostate hyperplasia (BHP). In the this study, root bark of p.africana were showed the presence of phytochemical constituents such as alkaloids, flavonoids, terpenoids, saponins, tannins, steroids, and phenols of ethyl acetate extracts of it and also confirms that the absence of saponins, terpenoids, and steroids in the hexane extracts of P.africana root bark. The root bark of P.africana was extracted with solvents of n-hexane, ethyl acetate, and methanol and their yields $1.3 \mathrm{~g}, 2 \mathrm{~g}$, and $12.6 \mathrm{~g}$, respectively. The orange organic extract of ethyl acetate $(2 \mathrm{~g})$ was subjected to column chromatography on silica gel and numbers of fractions were collected. That is, from the IR spectrum, the absorption band at $3400 \mathrm{~cm}^{-}$ ${ }^{1}$ shows the $\mathrm{O}-\mathrm{H}$ stretching that confirms the presence of a hydroxyl group. Also the strong absorption band at $2922 \mathrm{~cm}^{-1}$ shows the presence of the C-H stretching. Two strong absorption band at $1690 \mathrm{~cm}^{-1}$ and $1609 \mathrm{~cm}^{-1}$ shows the presence of the $\mathrm{C}=\mathrm{C}$ stretching of the olefinic group.

As a final point, from this study, the compound AYU was elucidated and characterised by incorporating by spectroscopic techniques such as IR spectral data, ${ }^{13} \mathrm{C}$ NMR, DEPT-135, and ${ }^{1} \mathrm{H}$ NMR spectral data obtained.

Despite the traditional use of this plant for the treatments of various ailments, in many parts of the world there is no more report on phytochemical analysis on the root bark of $P$. africana. This is provoked tricky to compare and contrasts my work with the relative of other work. Thus, this study may serve as baseline for researchers who are inspired and interested to conduct such type of research in the future.

\section{Acknowledgements}

The author would like to express thank a lot families for their support of finance sources for this study next to almighty one God.

\section{Competing Interests}

Authors have declared that no competing interests exist.

\section{References}

1. WHO (2011). Traditional medicines: global situation, issues and challenges, Geneva Switzerland.

2. Yibralign, Z. (2007). Phytochemical investigation on the stem bark of Croton macrostachyus, M.Sc. Thesis, Addis Ababa University, Ethiopia, pp 1-6.

3. Prakashrout, S., Chroundary, K.A., Kar, D.M., et al., (2009). Plants in traditional medicinal system-future source of new drugs, Journal of pharmacy and pharmaceutical sciences, 1, 2.

4. Zhang, X. (1999). The role of WHO in traditional medicine worldwide: Drug Information Journal, 33, 321326.

5. Jimu, L. (2011). Threats and conservation strategies for the African cherry ( $P$. africana) in its natural range, A review: Journal of Ecology and the Natural Environment, 3(4), 118-130.

6. Taxonomy, economic importance and genomics of Rosaceae, www.hort.purdue.edu /newcrop/janick.../rosaceae.pdf -United States, down loaded in Mar. 2020.

7. Bodeker, G., Van't Klooster, C., Weisbord, E. (2014). P. africana (Hook.f.) Kalkman: The overexploitation of a medicinal plant species and its legal context: J. Altern Complement Med., 20(11), 810-822.

8. Bii, C., Korir, R., Rugutt, J., Mutai, C. (2010). The potential use of $P$. africana for the control, treatment and management of common fungal and bacterial infections: Journal of Medicinal Plants Research, 4(11), 995-998.

9. Muluvi, G.M., Parich, A.,Schueler, S., et al., (2012). Bioactive constituents in P. africana: Geographical variation throughout Africa and associations with environmental and genetic parameters: Phytochemitry, 83, 70-78.

10. Mugaka, B.P., Erasto, P., Otieno, J.N., Mahunnah, R.A., Kaale, E. (2013). Comparison of N- Docosanol and $\beta$-Sitosterol Content in the leaf and Stem Bark of $P$. africana Collected from different Geographical Zones in Tanzania: International Journal of Pure \& Applied Bioscience, 1(6), 132-138. 
11. Stewart, K.M. (2003). The Aficana cherry (P. africana): Can lesson be learned from an over-exploited medicinal tree: Journal of Ethnopharmacology, 89, 3-13.

12. Dalle, G. (2004). Distribution and conservation status of $P$. africana in Ethiopia: Opportunities and constraints, PhD Thesis, Georg-August University, Goettingen, Germany, pp 75-90.

13. Sunderland TCH, Obama C. A preliminary market survey of the non-wood forest products of Equatorial Guinea. In: Non-wood forest products of Central Africa: current research issues and prospects for conservation and development (edited by T.C.H. Sunderland, L.E. Clark and P. Vantomme). FAO, Rome. $1999 ; 211-220$.

14. Cunningham AB, Mbenkum FT. Sustainability of harvesting Prunus africana bark in Cameroon: A Medicinal Plant in International Trade. People and Plants Working Paper 2 UNESCO, Paris; 1993.

15. Cunningham M, Cunningham AB, Schippmann U. Trade in Prunus africana and the implementation of CITES. German Federal Agency for Nature Conservation, Bonn. 1997; 52.

16. Dawson IK. Prunus africana: How agroforestry can help save an endangered medicinal tree. Agroforestry Today. 1997; 9(2):15-17.

17. Hall HB, O’Brien EM, Sinclair FL. Prunus africana: A Monograph. School of Agricultural and Forest Sciences, University of Wales, Bangor; 2000.

18. Garnick MB. The dilemmas of prostate cancer. Scientific American Magazine. 1994; 52-59.

19. Marcoli M, D'angelo L, Del Vecchio A, Caravaggi M, Lecchini S, Frigo GM, Crema A. Anti-inflammatory action of Pygeum africanum extract in the rat. Farmaci e Terapia. 1986; 3:135-137.

20. Wasson KM, Watts SA. Proscar (Finasteride) inhibits 5-alphareductase activity in the ovaries and testes of Lytechinus variegatus Lamarck (Echinodermata: Echinoidea). Comparative Biochemistry and Physiology C: Pharmacology, Toxicology \& Endocrinology. 1998; 120:425-431.

21. Chrispus, M., Mueni, N., Ndiku, H., Ramesh, F. (2014). Chemical Constituents Screening and in Vitro Antibacterial Assessment of Prunus Africana Bark Hydromethanolic Extract: Journal of Natural Sciences Research, 4(16), 2224-3186. 